\title{
Chapter 7 \\ Does Participating in National and Ethnic Associations Promote Migrant Integration? A Study with Young First- and Second-Generation Migrants
}

\author{
Daniela Marzana, Sara Alfieri, and Elena Marta
}

\subsection{Introduction: The Challenges of Migration and the Role of Social Participation in National and Ethnic Associations}

Research carried out in recent decades on the experiences of migrants in Western countries recognizes the complexity and multidimensionality of adaptive and integrative processes associated with the difficulties of living in a new sociocultural context.

Following an overview of the distinctive characteristics of different migrant generations, we present a brief review of studies that connect social participation with integration and multiculturalism. In this chapter we define social participation as the process by which individuals are "actively participating in the life of their communities" by joining associations and volunteering (Harvard School of Public Health/ MetLife Foundation, 2004; Pozzi, Pistoni, \& Alfieri, 2017). We then describe the results of a qualitative study that explored what integration meant for a group of young engaged migrants, how integrated they felt, and what role participation in associations, both national and ethnic, played in these young people's perception of integration. Next, we discuss our results, connecting them with the principal results found in the literature. We conclude with the implications of our research findings.

A large number of factors have been proposed as being associated with the adaptation and integration of different migrant generations. For the first generations these factors include sociodemographic variables (e.g., gender, age, length of stay in the host country, socioeconomic status), post-migration variables (e.g., acculturation factors), and social contextual variables (e.g., characteristics of the host country, perceived discrimination, social support, ethnic network) (Berry, 1997;

D. Marzana $(\bowtie) \cdot$ S. Alfieri $\cdot$ E. Marta

Catholic University of the Sacred Heart, Milan, Italy

e-mail: daniela.marzana@unicatt.it 
Bornstein, 2017; Brubaker, 2001; Giuliani, Olivari, \& Alfieri, 2017; Marzana, Alfieri, \& Marta, 2016; Musterd \& Ostendorf, 2009; Sam \& Berry, 2006). For the second generations - that is, those that did not directly experience migration in that they are the offspring of migrants - these factors are linked to the difficulties of maintaining the culture of origin with the same intensity and frequency as their parents; furthermore, they are less influenced by the values and practices of their family's country of origin (Brambilla, Manzi, \& Regalia, 2010; Crul \& Vermeulen, 2003; Kasinitz, 2008).

Adaptation and integration processes take on particular significance in some phases of the life cycle such as adolescence and young adulthood, when the construction of one's personal and social identity takes place (Arnett, 2003; Arnett \& Tanner, 2006; French, Seidman, Allen, \& Aber, 2006; Phinney, Horenczyk, Liebkind, \& Vedder, 2001). Constructing personal identity during migration is a complex developmental task because it requires the integration and involvement of at least two aspects that are prominent in first and second migrant generations: ethnic identity and national identity (Benet-Martínez \& Haritatos, 2005; Berry, 1990; Brambilla et al., 2010). For young migrants, this transition to bicultural identity goes hand in hand with the typical transition of this age group, which has to do with the transition to adulthood.

Most research (Rumbaut \& Komaie, 2010; Stepick, Stepick, \& Labissiere, 2008) on young migrants has distinguished between two generations:

(a) First generation: those who arrived in the new country and established themselves there with their own migration project: work, study, reunification with other family members, etc.

(b) Second generation: those who were born in the host country from migrant parents.

The difference between first-generation young adults and young adults of second generations lies in the fact that the former experience, among others, problems of finding acceptance and meeting expectations related to their migratory life while the latter generations not only have to face problems of acceptance but also the challenges related to their desire of living autonomously. This latter task is often only partially aligned with the family's migratory project and is influenced by an array of cultural references (Besozzi, 2009). Moreover, young second-generation migrants define themselves as belonging to the country where they live but struggle to be recognized as such by their parents and by the society in which they grew up (Volpato, 2011).

Young adults' and adolescents' participation in the life of their society is an important factor for their growth process, in that it promotes identity construction and also contributes to the functioning of democracies (Fattori, Pozzi, Marzana, \& Mannarini, 2015; Flanagan \& Levine, 2010). This has been widely studied in the psychosociological field (Berkman \& Glass, 2000; Jensen, 2003; Kawachi \& Berkman, 2000; Lundy, 2007; Marzana, Alfieri, \& Marta, 2016; Marzana, Pozzi, Fasanelli, Mercuri, \& Fattori, 2016; Thoits \& Hewitt, 2001; Vecina, Chacon, Marzana, \& Marta, 2013; Watts \& Flanagan, 2007). 
In recent years we have seen this research interest broaden to include young migrants engaged in coping with a dual transition: the transition to adulthood and integration into the new society (Chiaranzola \& Ardone, 2008). The research questions that guided this corpus of studies were: "Can young migrants' social participation be a strategy for creating a network of relationships, learning the culture, and redefining oneself?" and "Will participating in national and ethnic associations help migrants feel integrated into their community and society?". There are many ways that integration has been understood in the literature: for example, as work, academic, linguistic, legal integration, and so on. The meaning of integration that we use in the present paper is complex and multifaceted (De los Mozos, 2008; Penninx, 2003, 2005). It draws on aspects of identification with ethnic and national communities and includes both migrants' attitudes toward society and society's attitudes toward migrants.

Extending the concept of social participation to migrants means considering them not only in the position of "users" and receivers of services but also as activators of interventions and protagonists in solidarity movements. According to González, Martín, and de Castro Cardoso (2011), the higher the percentage of the migrant population participating in society, the higher the level of their integration into society. In this connection, Suárez-Orozco, Hernández, and Casanova (2015) carried out a study in the USA with the aim of exploring the social participation of young first- and second-generation Latino migrants in American life. The results of the study revealed a strong commitment on the part of the migrants to help others in a variety of ways: offering to be agents of change, volunteering on a regular basis, and mentoring and tutoring in order to help young people choose professions that can make a social contribution. Similar results were found in studies on other populations (Jensen, 2008; Rumbaut, 2008; Stepick et al., 2008).

In the field of migration, social participation can be an important instrument for social integration because it promotes the migrant's adaptation to the local context and allows him/her to actively express citizenship (Alarcón, 2011; Gele \& Harsløf, 2012).

In 2007 Flanagan, Cumsille, Gill, and Gallay conducted a study aimed at understanding what influence social participation carried out by foreign students had on their beliefs and values. The sample consisted of 1052 students of African, Arabic, European, and Latin American origin residing in the USA. The results of the study demonstrated that, controlling for age, gender, and cultural background, the young people involved in social participation tended to appreciate the hosting society, to commit themselves to supporting the democratic values promoted therein, and to experience a sense of community. This entailed, firstly, that participants enjoyed a high level of individual health and well-being (Eccles \& Gootman, 2002; Resnick et al., 1997); secondly, they felt more motivated to repay what they had received from the community through volunteerism.

Sonn and Fisher (1996) conducted a study in Australia with 23 people who were classified as colored in South Africa and were then residing in Melbourne. They were interviewed with an instrument to assess sense of community. The authors proposed that migrants' participation in intermediate structures such as school, 
religious groups, family bonds, and sporting and social organizations offered experiences of safety, belonging, a sense of stability, justice, and acceptance. Sonn (2002) conducted another study on South Africans who lived in Australia to try to understand the way in which a sense of community could be transferred from one context to another in the context of migration. He found that activity settings, including associations, provided migrants with the opportunity to participate in the new society and gave them a social role that allowed them to feel part of the community, generating a sense of "we-ness" and increasing well-being and quality of life.

In a qualitative study carried out in Andalusia (Taurini, Paloma, García-Ramírez, Marzana, \& Marta, 2017), aimed at exploring how participation in community influenced migrants' well-being, the authors found that it (1) increased bicultural skills, (2) developed social relations with members of the host community, (3) strengthened social bonds with members of one's own cultural group, (4) increased abilities to be an active citizen, and (5) changed prejudices toward one's cultural group in the host country.

A quantitative investigation of 700 young migrants (18-33 years old) in Italy (Marzana \& Alfieri, 2015; Marzana, Alfieri, \& Marta, 2016) explored the connection between participation in community and the perception of integration and wellbeing. The authors found that socially engaged young migrants, independently of social demographic differences, presented higher levels of bicultural identity, perception of integration, well-being, and a sense of community.

Research on migrants' participation has investigated the role of social participation both in ethnic associations - those that arise from the aggregation of foreign people residing in the host nation - and in national associations created by citizens of the host nation. However, there are few studies that have investigated the possible differences between being a volunteer in a national as opposed to an ethnic association. In this connection, Handy and Greenspan (2009) noted that the outcomes of participation in ethnic associations, as opposed to organizations composed only of groups of citizens native to the country, can be very different.

According to Schoeneberg (1985), there are two factors that usually distinguish national organizations from ethnic ones: (a) the fact that the latter have a dual orientation, toward the country of origin and toward the country of residence, and (b) that they offer diversified activities rather than activities related to one interest only. Schoeneberg (1985), in a study that was among the first in the field, asserted that the type of result that could be obtained by ethnic associations (segregation vs. integration) depended in large measure on the orientation and activities that they offered members and, on the positions, that they covered in the society in which they operated.

In later years, a study was conducted in Belgium by Jacobs, Phalet, and Swyngedouw (2004) on Moroccan, Turkish, and Belgian immigrants with a low educational level. The results revealed that the Turkish immigrants showed the highest level of ethnic engagement in the community, but the Moroccan immigrants had the highest level of political involvement. Moreover, the study drew a distinction 
between belonging to ethnic associations, which produced ethnic social capital, and belonging to mixed associations, which produced cross-cultural social capital.

Brettell (2005) studied the organizational life of Indian immigrants in the USA, finding that belonging to ethnic associations allowed immigrants to continue to speak their mother tongue and to transmit transnational and transcultural engagement to their children. Ethnic associations thus seem to promote the development of biculturalism in second-generation immigrants.

Paloma, García-Ramírez, de la Mata, and Association, A. M. A. L. (2010) argued that ethnic organizations could help build bridges between newcomers and the receiving society and empower society (Maton, 2008). The authors analyzed the experience of an Andalusian association that influenced the construction of the self and promoted community improvement. It is thus evident that the type of association does not have a single effect on integrative processes, but is associated with them through a variety of forms.

\subsection{A Study on Young First- and Second-Generation Migrants in Italy}

The research project presented herein originated within a broader project (Marzana $\&$ Alfieri, 2015) of which this is a qualitative follow-up study. The present work focused on young migrants who had to cope with a dual transition: (a) becoming adults and (b) finding the best possible adaptation between the two cultures to which they belonged, that of their country of origin and that of the host country.

The original study had involved young migrants between the ages of 17 and 36; of these, $56.8 \%$ were engaged in an association (63\% in Italian associations with the rest in ethnic or mixed associations), and $43.2 \%$ were not engaged. Using a selfreport questionnaire, we investigated variables related to life satisfaction and selfesteem; variables of knowledge about context; perception of one's own integration, ethnic identity, and national identity; and, finally, a sense of community. Results indicated that, in all the variables mentioned above, the young migrants who participated in their community had significantly higher means than their peers who did not participate.

The aims of the present qualitative study were to explore (1) the meaning that integration had for young migrants who participate in associations, (2) how integrated they felt, and (3) the role of social participation in associations, both Italian and ethnic, in the participants' perception of their integration.

Participants were 21 young migrants from sub-Saharan Africa, 9 males and 12 females, ranging in age from 18 to $28(M=22)$ and residing in Italy. Sixteen of the young migrants participated in ethnic associations, while five participated in Italian associations (with 5.41 years of involvement in the association, on average).

Semi-structured interviews were used to collect data. The interview was conducted on an individual basis by an Italian researcher in the offices of the associa- 
tions in which the young migrants were volunteering. The interview themes were based on the research aims. We identified a priori two thematic areas: meaning and perception of integration and the role of the Italian and ethnic associations in which the young migrants participated, exploring elements of the associative experience that promoted integration. Demographic information (age, marital status, country of birth, educational level, and profession) was also gathered. All interviews were carried out by the same researcher, lasted from 30 minutes to 1 hour, and were audiotaped and transcribed.

The transcripts from interviews were analyzed using thematic analysis, which is a method for identifying, analyzing, and reporting themes from the data (Braun \& Clarke, 2006). Researchers using this method have to choose between one of two analytical levels: the semantic/explicit level vs. the latent/interpretative level (Boyatzis, 1998). The analysis in the present work was carried out at the semantic level, in other words, the level of meaning.

\subsubsection{Principal Findings and Discussion}

\section{Meaning of Integration}

The interviewees attributed a variety of meanings to the word "integration," independently of the typology of the association to which the participants belonged. One meaning of integration that came to light was respect and value of diversity, independently of the migrants' generation. According to the interviewees, each person's peculiarities, in both individual and cultural terms, were a source of enrichment as much for the young migrants as for the host society and must not be seen as reasons to discriminate:

I think that we have to keep in mind that we are all different, but the point that should be emphasized is reciprocal respect. Respect for difference. We are always saying, "Human beings are all equal." No! Human beings are different and we have to respect one another's diversity. That is utopian talk, not reality, the reality is that we are all different. We have to always respect one another's diversity and value it ${ }^{1}\left(\mathrm{~L}\right.$., male, age $\left.22^{2}\right)$.

A second meaning that emerged, independently of the interviewees' generation, was "integration as responsibility": the possibility of being active in the host society and working for the good of the country. This second meaning went beyond the idea of merely accepting rules and adapting to one's context, focusing, instead, on what one can do to be a resource for society:

Everyone has to be responsible and aware of his or her role in society and therefore to move and want what is good for everyone and become active for the good of the country (F., female, 22).

\footnotetext{
${ }^{1}$ All the quotes are translated from Italian.

${ }^{2}$ The capital letter is in place of the name to guarantee anonymity.
} 
Important distinctions were found in how integration was defined depending the interviewees' generation, however. Most of the first-generation young people believed that integration involved adapting to Italians' attitudes and ways of doing things, respect for the rules, and renouncing something of oneself. In fact, they maintained that the factors that could define an integrated person were knowledge of the host country's language and compliance with that culture's customs:

I think about a boy or a foreign family who arrives in a country and after years they are integrated in the system, they feel part of the system, they work, respect the rules, understand that these rules are different from the ones in their own country, but they accept them and follow them (S., m, 27).

Even if I'm a foreigner, I condemn people who go to another country and want to impose their culture and their laws. In my country we say "When you go to a country and you find everyone naked, you also have to be naked." If you come here, you have to do things like the Italians. When we go to an Islamic country, they require the women to put on a burqa, why is it that when they come here they can't do things like we do? (M., f, 24).

The second-generation youth, on the other hand, saw integration as the possibility of becoming part of a social group, of collaborating, and not only being limited to coexisting and merely tolerating one another. This suggested that integration is a reciprocal rapprochement, which also underscored the role of the host society. Many of the young people, in fact, believed that the task of Italians was to open up to foreigners, forcing themselves to get to know people before judging them, and they evoked the bidirectionality of the integrative process that must involve both of the interested parties:

Integrating in the sense of sharing, being with people, talking, getting to know their culture (J.B., m, 26).

[For me integration is] many elements put together that make an organization, in the sense that they collaborate with one another, they understand one another, they know how the group is made up, they live one with the other (N., f, 20).

As can be seen from the above, integration had to do with identification for the second-generation youth: being integrated meant feeling part of something and the ability to be oneself without being judged. It seemed that the young people who had been in Italy for a longer time cared more about the connection between integration and definition of identity. In fact, they were the ones who were driven to belong to associations by a desire for personal understanding and development, to understand who they were, and to keep together aspects of the two cultures. They were the ones who pointed out that one of the difficulties that a person can encounter after one's own or one's family's migratory process is the loss of identity, and they were the ones who maintained that belonging to an association could contribute to the definition of identity. Finally, it should be noted that two secondgeneration young women wished to emphasize that the word "integration" does not only refer to the modalities of reception and integration of foreigners into a new society, but that it was a theme that could also be extended to other situations and contexts: 
I don't even see it only as integration of foreigners into Italy, $[\ldots]$ integration is bigger than that, when, for example, you begin a new course of study and you have to enter, when I met my boyfriend, integration was going to meet the people who love him, his family and friends (P., f, 23).

It's like when you finish a job and you have to begin a new one you feel a little uncomfortable because you don't know your colleagues and so you feel a little uncomfortable, or children when they have to change school, they have to change everything, classmates, teachers, friends (C., f, 27).

This suggests that it is impossible to avoid such an important theme, which involves and challenges all of us as people and does not only concern foreigners or the few people who are interested in it.

\section{Perception of One's Own Integration}

Perception of integration was very different in the generations under consideration, and those differences played out in the realm of ethnic and Italian identity. The first-generation youth admitted that they were less, or not at all, integrated compared to the second-generation youth and often defined themselves only in terms of ethnic identity ("I am Moroccan," "I am Tunisian"). Some of them emphasized the impossibility of forgetting their origins and talked about their desire to return to their place of birth. Some of them stressed that integration is a utopian idea because Italians were often more favorable to accepting people who were more similar to themselves, those who had a lighter skin color and spoke their language correctly. In most cases, an idea of partial acceptance came out, limited to the few who were already integrated because they had been born here or were already more easily integrated into society. Many of these young people, while acknowledging the positive role played by some Italians, believed that, in general, Italians as a population are closed to foreigners and not very interested in learning about differences, and they talked about the suffering caused by being always and everywhere perceived as an illegal immigrant, despite all their efforts. As stated by L., who came to Italy to take a second degree in medicine:

If you say the word "integration," I think it remains a word because integration in itself does not exist. In theory integration should be from two sides: I as a foreigner have to try to integrate and Italians also have to let me do it, it isn't like this (L., m, 22).

The second-generation youth talked about their dual belonging (Italian and migrant), or they defined themselves as exclusively Italian, independently of how others saw them:

Not everyone thinks about it in the same way. I can say that I'm integrated, some others will say that I'm not, the important thing is what I think. (G., f, 25).

Fokkema and de Haas (2011), in a study drawing on a dataset of four African migrant groups in Spain and Italy, demonstrated that the younger the person was when he/she migrated, the greater his/her possibilities of integrating into society were. 
This latter aspect could also be connected to the fact that the second-generation youth were in the 18-27 years age bracket, with a median age of about 21 years. Many of them had just completed or were in the middle of the process of obtaining citizenship, which can be requested for the children of foreign parents after they come of age according to Italian law, but is often obtained some years later. Obtaining citizenship and the difficulty of the process certainly put the young person's belonging into question, just as this should cause us to reflect on our concept of citizenship (Granata, 2011). The tortuous process of obtaining official recognition of one's belonging to the Italian nation, or its recent acquisition, could push second-generation youth to question their own identity even more and to reshape it. Many of these young people talked about having developed a bicultural identity, and some of them made it clear that it required them to locate themselves in between two cultures.

\section{Role of Social Participation in Associations in Promoting Integration}

The interviewees unanimously stated that participating in associations (Italian and ethnic) enabled them to feel more integrated and that participation was very useful for young people who have recently arrived in a new country. Several studies have shown that social participation is a catalyst for the construction of identity because it spurs one to experience agency, social relatedness, moral and political awareness (Yates \& Youniss, 1996), and self-efficacy and self-esteem (Born, Marzana, Alfieri, \& Gavray, 2015; Marta \& Pozzi, 2007). In fact, migrants require these elements in order to develop the critical thinking that leads them to comprehend the conditions of difficulty in which they are living and which help them feel that they possess the necessary means to face their life situation (García-Ramírez, Manuel, Paloma, \& Hernández-Plaza, 2011). In this way, the individual develops "multiculturality" and becomes capable of maintaining one's roots as a reference point but is open to the possibility of learning new cultural elements that are useful and positive for one's own process of self-construction (Garza \& Gallegos, 1985) and for the betterment of the social condition of one's ethnic group (Paloma \& Manzano-Arrondo, 2011; Prilleltensky \& Arcidiacono, 2010).

According to the young people interviewed, both types of associations (Italian and ethnic) promoted the host country's culture, values, and language; that is, they guaranteed the development of useful intercultural skills for relating to the nativeborn population. It did not matter whether one spoke or interacted with Italians or with migrants of the same or other countries: participating in associations, in the words of the interviewees, was a good method for entering into dialogue and learning which behaviors to use in specific situations in the Italian context:

This type of group teaches you certain values and certain aspects that society does not teach you. $(\mathrm{S}, \mathrm{m}, 23)$

Moreover, all the youth who were interviewed agreed that partaking in associations allowed them to broaden their relational networks. McLaughlin and Talbert (2006) demonstrated that participants belonging to minority ethnic groups who experienced 
being valued by other members of the community felt more motivated to integrate into the new society; this led them to have a more positive view of other people and to feel included and safe (Zeldin, 2002; Zeldin \& Topitzes, 2002).

Some activists in ethnic associations held a different opinion, however, claiming that partaking in ethnic associations risked causing more closure or the marginalization of its members rather than allowing them to integrate into the host society:

So, remaining amongst ourselves does not allow us to integrate. I understood this after two years and I tried to separate a little because I cannot live here and be always with my countrymen (L., m, 22).

Ethnic associations also ensured that migrants could keep strong connections to their origins, remembering the traditions and customs of their homeland, as well as economically supporting their compatriots, as A. explained:

Sometimes there are people who live in isolated places where there aren't many foreigners, and at least if they come [to our association] they can find some companionship like a family reunion. (A, $\mathrm{m}, 23)$.

The national and ethnic associations had very similar characteristics. Both supported social integration and intercultural exchange in that they were perceived as an opportunity to meet people from different cultures. Both of these association types were seen as opportunities to feel useful, and both promoted agency; that is, feeling that one is a resource for the country and able to improve oneself. All of these aspects were clearly summarized in this young migrant's words:

You feel you are a part of the country, you feel you are a resource, you feel you belong, that you aren't a foreigner $(\mathrm{H}, \mathrm{m}, 19)$.

\subsubsection{Conclusion}

The results of this study suggest that identity definition is different for each generation, ranging from ethnic identity for the first generation, bicultural identity for the generation in between and the second generation, to a concept of the self as Italian. Nevertheless, in agreement with Granata (2011), we believe that attempts to reduce identity to a single dimension are oversimplifications with the worrisome outcome of eliminating the complexity inherent in persons, each with his/her own peculiarities. In a globalized, dynamic, and fluid world, a plurality of belongings and selfdefinitions characterize most people and, even more so, individuals who have a migratory event in their history or family background. The young people in this study attest to this, having found a variety of ways to define themselves, carefully avoiding classifying themselves in overly simplistic ways. Some define themselves only as a person; some refer to their name to express who they are; some define themselves based on their parents; and some, finally, see themselves as global citizens or as Italians with a different origin story. 
The longer young migrants live in Italy, the more their sense of belonging to the country seems to be strengthened. However, in most cases they do not seem to lose the connection to their origins. We found consensus among the participants regarding the positive effects of social participation on integration, with some differences depending on whether they participated in national or ethnic associations. It appears that ethnic associations run the risk of closing themselves off from, rather than opening to, the host society, while Italian associations allow participants to feel of use to the country, thus developing the hope for sense of civic engagement.

What seems to be missing in both the Italian and ethnic associations is the creation of a collective action that would make it possible not only to question but also to transform social structures (Moane, 2003; Paloma \& Manzano-Arrondo, 2011; Pozzi, Fattori, Bocchiaro, \& Alfieri, 2014; Prilleltensky, 2003, 2008). It thus seems crucial to ensure that the passage "from reflection to action" is accomplished in order to promote empowering community narratives (Balcazar et al., 2012) and to develop sociopolitical empowerment. The sociopolitical empowerment of migrants is indispensable to counter the inequality that they experience and to allow them to become politically active members of society who contribute to its development (Montero, 2009).

\subsection{Implications}

The "European Foundation for the Improvement of Living and Working Conditions" (2006) states that social participation is a fundamental element for fostering the integration of migrants. In the 2006 report, the authors argue that local institutions should promote this type of activity through incentives, public relations, and financial support. In particular, in order to develop an integrative process, it might be useful to support migrant associations, which are examples of self-organization and represent the roots of democracy and civil society. Further indications come from Flanagan, Gallay, Gill, Gallay, and Nti (2005) and Zeldin and Topitzes (2002), who identified another instrument of integration: teaching ethical and democratic values in schools in order to promote an interest in politics in the new generation of migrants.

Therefore, the efficacy of designing interventions for migrants that not only provide services but also allow them to take an active position is clear. The active engagement of young migrants is enriching for themselves and for the entire community, promoting dialogue and positive coexistence. Projects aimed at developing a sense of citizenship and social participation should encourage foreigners and native-born persons to join voluntary associations in order to promote integration, intercultural exchange, and active citizenship.

Traditionally citizenship is the belonging of a person to a state. Citizenship is therefore a concept that implies the belonging of the person to an institutionalized political community, the state, with the assumption of a set of rights and duties. 
In Italy, for example, it is considered an Italian citizen from birth the child of a father or mother citizen at the time of his birth, wherever it takes place. The principles on which Italian citizenship is based are (a) the transmissibility of citizenship by descent "iure sanguinis," (b) the purchase "iure soli" (by birth on the territory) in some cases, and c) the possibility of dual citizenship by a formal request.

For many scholars, citizenship has been devalued as a tool of integration (Joppke \& Morawska, 2014). As social and economic entitlements are legitimized not by nation-states and national policy but by the discourse of "universal personhood," international norms, and treaties, the traditional association between citizenship and rights, between the national state and the individual, has been broken David Jacobson claims in Rights Across Borders Jacobson (1996). We can suppose then that integration occurs independently of national citizenship. The growing number of foreigners, but especially the children of migrants present in Italy, should make us question and reflect on the inadequacy of our categories of citizenship and integration, and the phenomenon of associative engagement could certainly signal a turning point away from a type of thinking that has not kept up with the times. The person who commits to the good of his/her country is a citizen, enthusiastically donating time to make it a better place; the notion of citizenship should extend to the will to activate oneself in one's own life context. It is in this sense that the results of this study reveal interesting perspectives that are not only theoretical but also practical, demonstrating the positive implications of participating in associations for the process of integration and identity definition in young migrants in relationship with the native born for the construction of a fairer multicultural society.

\section{References}

Alarcón, V. B. (2011). Voluntariado e inmigración. Tendencias y perspectivas. In Actas del I Congreso Internacional sobre Migraciones en Andalucía (pp. 1251-1258). Granada, Spain: Instituo de Migraciones.

Arnett, J. J. (2003). Conceptions of the transition to adulthood among emerging adults in American ethnic groups. New Directions for Child and Adolescent Development, 100, 63-76.

Arnett, J. J., \& Tanner, J. L. (Eds.). (2006). Emerging adults in America: Coming of age in the 21st century (p. 3). Washington, DC: American Psychological Association.

Balcazar, F. E., Suarez-Balcazar, Y., Adames, S. B., Keys, C. B., García-Ramírez, M., \& Paloma, V. (2012). A case study of liberation among Latino immigrant families who have children with disabilities. American Journal of Community Psychology, 49(1-2), 283-293.

Benet-Martínez, V., \& Haritatos, J. (2005). Bicultural identity integration (BII): Components and psychosocial antecedents. Journal of Personality, 73(4), 1015-1050.

Berkman, L. F., \& Glass, T. (2000). Social integration, social networks, social support, and health. Social Epidemiology, 1, 137-173.

Berry, J. W. (1990). Psychology of acculturation. In J. Berman (Ed.), Crosscultural perspectives: Nebraska symposium on motivation (pp. 475-488). Lincoln, NE: University of Nebraska Press.

Berry, J. W. (1997). Immigration, acculturation, and adaptation. Applied Psychology, 46(1), 5-34.

Besozzi, E. (2009). Una generazione strategica. In E. Besozzi, M. Colombo, \& M. Santagati (Eds.), Giovani stranieri, nuovi cittadini. Le strategie di una generazione ponte (pp. 13-56). Milan, Italy: Franco Angeli. 
Born, M., Marzana, D., Alfieri, S., \& Gavray, C. (2015). "If It Helps, I'll Carry On”: Factors supporting the participation of native and immigrant youth in Belgium and Germany. The Journal of Psychology, 149(7), 711-736.

Bornstein, M. H. (2017). The specificity principle in acculturation science. Perspectives on Psychological Science, 12(1), 3-45.

Boyatzis, R. E. (1998). Transforming qualitative information: Thematic analysis and code development. Thousand Oaks, CA: Sage.

Brambilla, M., Manzi, C., \& Regalia, C. (2010). Relazioni Famigliari e Benessere nelle Seconde Generazioni dell'Immigrazione: Il Ruolo dei Nonni ["Family Relations and Wellbeing in the Second Generations of Immigrants: The Role of Grandparents"]. Rivista di Studi Familiari, 2, 82-95.

Braun, V., \& Clarke, V. (2006). Using thematic analysis in psychology. Qualitative Research in Psychology, 3(2), 77-101.

Brettell, C. (2005). Voluntary organizations, social capital, and the social incorporation of Asian Indian immigrants in the Dallas-Fort worth metroplex. Anthropological Quarterly, 78(4), 853-882.

Brubaker, R. (2001). The return of assimilation? Changing perspectives on immigration and its sequels in France, Germany, and the United States. Ethnic and Racial Studies, 24, 531-548.

Chiaranzola, C., \& Ardone, R. (2008). Processi di adattamento in giovani albanesi immigrati. In E. Scabini \& G. Rossi (Eds.), La migrazione come evento familiare. Milano, Italy: Vita e pensiero.

Crul, M., \& Vermeulen, H. (2003). The second generation in Europe. International Migration Review, 37(4), 965-986.

De Haas, H., \& Fokkema, T. (2011). The effects of integration and transnational ties on international return migration intentions. Demographic research, 25, 755-782.

De los Mozos, F. J. Á. (2008). Immigrant organizations as a factor of social integration. In Migrations in a global context (p. 27). Bilbao, Spain: University of Deusto.

Eccles, J., \& Gootman, J. A. (2002). Community programs to promote youth development. Washington, DC: National Academy Press.

European Foundation for the Improvement of Living and Working Conditions. (2006). Fourth European working conditions survey. European Foundation for the Improvement of Living and Working Conditions.

Fattori, F., Pozzi, M., Marzana, D., \& Mannarini, T. (2015). A proposal for an integrated model of prosocial behavior and collective action as the expression of global citizenship. European Journal of Social Psychology, 45(7), 906-917. https://doi.org/10.1002/ejsp.2154

Flanagan, C., \& Levine, P. (2010). Civic engagement and the transition to adulthood. The Future of Children, 20(1), 159-179.

Flanagan, C. A., Cumsille, P., Gill, S., \& Gallay, L. S. (2007). School and community climates and civic commitments: Patterns for ethnic minority and majority students. Journal of Educational Psychology, 99(2), 421.

Flanagan, C. A., Gallay, L. S., Gill, S., Gallay, E., \& Nti, N. (2005). What does democracy mean? Correlates of adolescents' views. Journal of Adolescent Research, 20(2), 193-218.

French, S. E., Seidman, E., Allen, L., \& Aber, J. L. (2006). The development of ethnic identity during adolescence. Developmental Psychology, 42(1), 1-10.

García-Ramírez, M., Manuel, L., Paloma, V., \& Hernández-Plaza, S. (2011). A liberation psychology approach to acculturative integration of migrant populations. American Journal of Community Psychology, 47(1-2), 86-97.

Garza, R. T., \& Gallegos, P. I. (1985). Environmental influences and personal choice: A humanistic perspective on acculturation. Hispanic Journal of Behavioral Sciences, 7(4), 365-379.

Gele, A. A., \& Harsløf, I. (2012). Barriers and facilitators to civic engagement among elderly African immigrants in Oslo. Journal of Immigrant and Minority Health, 14(1), 166-174.

Giuliani, C., Olivari, M. G., \& Alfieri, S. (2017). Being a "Good" Son and a "Good" Daughter: Voices of muslim immigrant adolescents. Social Sciences, 6(4), 142. 
González, M. C., Martín, S. C., \& de Castro Cardoso, D. (2011). Voluntariado e inmigración. Revista de Teología y Pastoral de la Caridad, Corintios, 23(139), 110-125.

Granata, A. (2011). Sono qui da una vita. Dialogo aperto con le seconde generazioni [I have been here for a lifetime. An open dialogue with second generations] (pp. 1-166). Roma, Italy: Carocci Editore.

Handy, F., \& Greenspan, I. (2009). Immigrant volunteering: A stepping stone to integration? Nonprofit and Voluntary Sector Quarterly, 38(6), 956-982.

Harvard School of Public Health/MetLife Foundation. (2004). Reinventing aging: Baby boomers and civic engagement. Boston, MA: Harvard School of Public Health, Center for Health Communication.

Jacobs, D., Phalet, K., \& Swyngedouw, M. (2004). Associational membership and political involvement among ethnic minority groups in Brussels. Journal of Ethnic and Migration Studies, 30(3), 543-559.

Jacobson, D. (1996). Rights across borders: Immigration and the decline of citizenship. Leiden, The Netherlands: Brill.

Jensen, L. A. (2003). Coming of age in a multicultural world: Globalization and adolescent identity formation. Applied Developmental Science, 7, 188-195.

Jensen, L. A. (2008). Immigrants' cultural identities as sources of civic engagement. Applied Development Science, 12(2), 74-83.

Joppke, C., \& Morawska, E. (2014). Integrating immigrants in liberal nation-states: Policies and practices. In Toward assimilation and citizenship: Immigrants in liberal nation-states (pp. 1-36). London, UK: Palgrave Macmillan.

Kasinitz, P. (2008). Becoming American, becoming minority, getting ahead: The role of racial and ethnic status in the upward mobility of the children of immigrants. The Annals of the American Academy of Political and Social Science, 620(1), 253-269.

Kawachi, I., \& Berkman, L. (2000). Social cohesion, social capital, and health. In L. F. Berkman \& I. Kawachi (Eds.), Social epidemiology. New York, NY: Oxford University Press.

Lundy, L. (2007). "Voice" is not enough: Conceptualising Article 12 of the United Nations Convention on the Rights of the Child. British Educational Research Journal, 33(6), 927-942.

Marta, E., \& Pozzi, M. (2007). La Psicologia del Volontariato. Roma, Italy: Carocci.

Marzana, D., \& Alfieri, S. (2015). Mi impegno in tutte le lingue del mondo. L'attivismo dei giovani immigrati come promotore di benessere e integrazione. Soveria Mannelli: Rubbettino.

Marzana, D., Alfieri, S., \& Marta, E. (2016). The multidimensional nature of young immigrants' well-being. Rivista Internazionale di Scienze Sociali, 1(1), 21-40.

Marzana, D., Pozzi, M., Fasanelli, R., Mercuri, F., \& Fattori, F. (2016). The relation between participatory social practices and social representations of citizenship: A pilot study of Italian young adults. Voluntas, 27, 1152-1170. https://doi.org/10.1007/s11266-015-9607-x

Maton, K. I. (2008). Empowering community settings: Agents of individual development, community betterment, and positive social change. American Journal of Community Psychology, 41, 4-21.

McLaughlin, M. W., \& Talbert, J. E. (2006). Building school-based teacher learning communities: Professional strategies to improve student achievement (Vol. 45). New York, NY: Teachers College Press.

Moane, G. (2003). Bridging the personal and the political: Practices for a liberation psychology. American Journal of Community Psychology, 31, 151-169.

Montero, M. (2009). Community action and research as citizenship construction. American Journal of Community Psychology, 43(1-2), 149-161.

Musterd, S., \& Ostendorf, W. (2009). Residential segregation and integration in the Netherlands. Journal of Ethnic and Migration Studies, 35(9), 1515-1532.

Paloma, V., García-Ramírez, M., de la Mata, M., \& Association, A. M. A. L. (2010). Acculturative integration, self and citizenship construction: The experience of Amal-Andaluza, a grassroots organization of Moroccan women in Andalusia. International Journal of Intercultural Relations, 34(2), 101-113. 
Paloma, V., \& Manzano-Arrondo, V. (2011). The role of organizations in liberation psychology: Applications to the study of migrations. Psychosocial Intervention, 20(3), 309-318.

Penninx, R. (2003). Immigration without integration: A recipe for disaster. In Greek conference on managing migration, disponible en http://www.migrationpolicy.org/pubs/EuropeanResources. php.

Penninx, R. (2005). Integration of migrants: Economic, social, cultural and political dimensions. The new demographic regime: Population challenges and policy responses, 5, 137-152.

Phinney, J. S., Horenczyk, G., Liebkind, K., \& Vedder, P. (2001). Ethnic identity, immigration, and well-being: An interactional perspective. Journal of Social Issues, 57(3), 493-510.

Pozzi, M., Fattori, F., Bocchiaro, P., \& Alfieri, S. (2014). Do the right thing! A study on Social Representation of Obedience and Disobedience. New Ideas in Psychology, 35, 18-27. https:// doi.org/10.1016/j.newideapsych.2014.06.002

Pozzi, M., Pistoni, C., \& Alfieri, S. (2017). Verso una psicologia della partecipazione: Una sistematizzazione teorica dei rapporti tra le azioni nel sociale [Toward a Psychology of Participation: A theoretical analysis of the relationship between actions in the social context]. Psicologia Sociale, 3, 253-276. https://doi.org/10.1482/87884

Prilleltensky, I. (2003). Understanding, resisting, and overcoming oppression: Toward psychopolitical validity. American Journal of Community Psychology, 31(1-2), 195-201.

Prilleltensky, I. (2008). The role of power in wellness, oppression, and liberation: The promise of psychopolitical validity. Journal of Community Psychology, 36(2), 116-136.

Prilleltensky, I., \& Arcidiacono, C. (2010). Modello ecologico e migranti: Benessere, giustizia e potere nella vita degli immigrati. Psicologia di Comunita'. Milano: Franco Angeli.

Resnick, M. D., Bearman, P. S., Blum, R. W., Bauman, K. E., Harris, K. M., Jones, J., ... Ireland, M. (1997). Protecting adolescents from harm: Findings from the National Longitudinal Study on Adolescent Health. JAMA, 278(10), 823-832.

Rumbaut, R. G. (2008). Reaping what you sow: Immigration, youth, and reactive ethnicity. Applied Development Science, 12(2), 108-111.

Rumbaut, R. G., \& Komaie, G. (2010). Immigration and adult transitions. The Future of Children, 20(1), 43-66.

Sam, D. L., \& Berry, J. W. (2006). The Cambridge handbook of acculturation psychology. Cambridge, UK: Cambridge University Press.

Schoeneberg, U. (1985). Participation in ethnic associations: The case of immigrants in West Germany. International Migration Review, 19, 416-437.

Sonn, C. C. (2002). Understanding the process through sense of community. In Immigrant adaptation (pp. 205-222). New York, NY: Springer US.

Sonn, C. C., \& Fisher, A. T. (1996). Psychological sense of community in a politically constructed group. Doctoral dissertation, John Wiley \& Sons.

Stepick, A., Stepick, C. D., \& Labissiere, Y. (2008). South Florida's immigrant youth and civic engagement: Major engagement: Minor differences. Applied Development Science, 12(2), $57-65$.

Suárez-Orozco, C., Hernández, M. G., \& Casanova, S. (2015). "It’s sort of my calling": The civic engagement and social responsibility of Latino immigrant-origin young adults. Research in Human Development, 12(1-2), 84-99.

Taurini, E., Paloma, V., García-Ramírez, M., Marzana, D., \& Marta, E. (2017). Effects of the community engagement of migrants on their well-being: The case of Moroccan leaders in southern Spain. Journal of Prevention \& Intervention in the Community, 45(1), 32-43.

Thoits, P. A., \& Hewitt, L. N. (2001). Volunteer work and well-being. Journal of Health and Social Behavior, 42(2), 115-131.

Vecina, M. L., Chacon, F., Marzana, D., \& Marta, E. (2013). Volunteer engagement and organizational commitment in non-profit organizations: What makes volunteers remain within organizations and feel happy? Journal of Community Psychology, 41(3), 291-302.

Volpato, C. (2011). Nuovi cittadini: I giovani immigrati tra accoglienza e rifiuto. Milano, Italy: Unicolpi. 
Watts, R. J., \& Flanagan, C. (2007). Pushing the envelope on youth civic engagement: A developmental and liberation psychology perspective. Journal of Community Psychology, 35(6), 779-792.

Yates, M., \& Youniss, J. (1996). Community service and political-moral identity in adolescents. Journal of Research on Adolescent, 6, 271-284.

Zeldin, S. (2002). Sense of community and adult beliefs towards adolescents and youth policy in urban neighborhoods and small cities. Journal of Youth and Adolescence, 31, 331-342.

Zeldin, S., \& Topitzes, D. (2002). Neighborhood experiences, community connection, and positive beliefs about adolescents among urban adults and youth. Journal of Community Psychology, 30(6), 647-669.

Open Access This chapter is licensed under the terms of the Creative Commons Attribution 4.0 International License (http://creativecommons.org/licenses/by/4.0/), which permits use, sharing, adaptation, distribution and reproduction in any medium or format, as long as you give appropriate credit to the original author(s) and the source, provide a link to the Creative Commons license and indicate if changes were made.

The images or other third party material in this chapter are included in the chapter's Creative Commons license, unless indicated otherwise in a credit line to the material. If material is not included in the chapter's Creative Commons license and your intended use is not permitted by statutory regulation or exceeds the permitted use, you will need to obtain permission directly from the copyright holder.

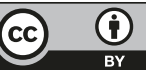

